\title{
Effects of Firm Size on Enterprise Risk Management of Listed Firms in Kenya
}

\author{
Christopher Kibet Yegon ${ }^{1}$, Jeoffrey Gekara Mouni ${ }^{2}$, Kenneth Wanjau ${ }^{3}$ \\ 1. Directorate of Technical Accreditation and Quality assurance, Ministry of Education Science and \\ Technology, Nairobi, Kenya. \\ 2. School of Business, East Africa University, Nairobi, Kenya. \\ 3. School of Human Resource Development, Jomo Kenyatta University of Agriculture and Technology, Juja, \\ Kenya.
}

\begin{abstract}
The purpose of this study was to investigate the effects of firm size on enterprise risk management for the listed firms in Kenya. Effectiveness of enterprise risk management is measured by financial performance of the listed firms. A descriptive research design was used. Theoretically, ERM adds value to an organization, however there is disagreement among scholars on whether ERM add value to a firm that adopt ERM. This study investigated the effects of firm's size on ERM measured in terms of financial performance of the listed firms in Kenya. A descriptive research design was used and the study population was the managers heading ERM departments in the listed firms. A survey sheet was used to collect secondary data from annual financial statements of each of the listed firms; primary data was collected using questionnaires. Data collected was analyzed using descriptive statistics and regression analysis models. The relationship between independent variable and dependent variable was analyzed using linear regression models. The hypothesis was tested using F-test at 5\% level of confidence. The results were presented using pie charts, tables and graphs. The finding from the study was compared with the empirical literature as well as the theoretical literature.
\end{abstract}

Key words: Firm's size, ERM, Listed Firms, Financial performance

\section{Introduction}

Firm size is the value of the business measured in terms of net assets. It is the total realizable value of a business (Nofsinger, Adair \& Cornett, 2009). Despite the fact that enterprise risk management (ERM) has gained momentum globally, various risks continue to increase and new risks evolve (Rasid \& Golshan, 2012). According to AM Best company risk report of 2013, Kenya was rated at CRT 5. The CRT rating was arrived after looking at the following risks; political, economy and financial risks. Financial system risk was rated high due to weak regulatory regime which does not meet global standards or best practices in the area of securities, business, accounting, insurance or banking (AM Best, 2013). In a survey done in Kenya among Chief executive officers (CEOs), $90 \%$ felt that risks was not being well managed, and top rated risks were affecting; financial markets, data privacy and security, completion and reputation and brand rated at 64\%, 58\%, 58\% and 56\% respectively (PWC, 2012).

\subsection{Theoretical Review}

It is argued that as a firm expand in size, risks facing it also increases. However, with adequate resources at its disposal it is able to dedicate greater resources to risk management (Golshan \& Rasid). Yazid, Razali and Hussin (2012) argued that well managed company's assets are extremely useful in supporting activities that could provide overall benefits to the company and shareholders. The consequence of weak ERM program can lead to huge losses due to disruption in business operations and high costs incurred to mitigate the risks. ERM is geared to address risks that can occur to a business organization such as financial risk, strategic risk and operation risk (Tazhir \& Razali, 2010). What has led to high rate of business risks include; complexities of business transactions, advances in technology, globalization and high speed in product life cycles. Similarly, the overall pace of change continues to increase the volume and the scale of risks facing organizations (Beasley, Hancock \& Branson, 2009). According to Economic Intelligence 59\% (106 out of 316) of the respondents felt that credit crisis and growing regulatory pressure has forced firms to scrutinize their risk management practices in detail (Watt, 2008). In addition, financial crisis, credit rating agencies and the pressure from the exchange has also increased the clamor for effective risk management and oversight practices (COSO, 2009).

\subsection{Enterprise Risk Management: Kenya Perspective}

Enterprise risk management in Kenya is weak, according to a survey done by PricewaterhouseCoopers in Kenya in 2011 on risk, $81 \%$ of the chief executive officers (CEOs) interviewed from various firms felt that 
risk to their organizations is increasing and traditional risks were evolving (PWC, 2012). Waweru and Kisaka (2011) examined the state of ERM in Kenya and found out that there was positive relationship between firm's size on ERM and financial performance of listed firms in Kenya. According to Deloitte and Touche (2012) traditional risks such as; operational, regulatory and market was rated at 95\%, 89\% and $83 \%$ respectively as the key risks affecting firms in Kenya. This means that ERM framework in Kenya is not effective or inadequate.

Despite the fact that majority (94\%) of commercial banks and financial institutions in Kenya had developed ERM framework according to CBK guidelines of 2005, 74\% (32) of the institutions had challenges due to weak ERM system and this had increase risk affecting the firms (CBK, 2010). The main cause of increase in risk was; complexity, unpredictability, evolving risks and globalization of trading activities (PWC, 2012). According to the Deloitte ERM survey report of 2012 for the financial service industry, risk governance was identified to be critical in risk management. However, the findings of the report showed that a few (29\%) number of institutions had put in place proper governance models to oversee risk management (Deloitte, 2012). Weak ERM has affected the performance of Kenya as a country in terms of competiveness (KIPPRA, 2009). Kenya was ranked in position eighty six (86) in terms of GDP among two hundred and seven (207) countries while in attractiveness as a business destination it was ranked at number seventy two (72) out of one hundred and seventy eight (178) countries. In comparison with Singapore, Taiwan and Malaysia which were ranked in position six (6), eight (8) and nine (9) respectively (KIPPRA, 2009).

According to Deloitte and Touche survey report of 2012, 85\% of the respondents felt that ERM was adding value to their business since it reduces volatility and enhances liquidity problem. The ERM legal framework in Kenya is contained in the Capital Market Authority regulations on corporate governance of 2002 Legal Notice Number 3362 (Republic of Kenya, 2002). Since the legal notice did not require firms to disclose measures taken to manage risk, then it was difficult to evaluate effectiveness of ERM.

Objective of the study was to investigate the influence of firm's characteristics on financial performance of listed firms in Kenya.

\subsection{Statement of the Problem}

Enterprise risk management in Kenya continue to be a problem, this is manifested in high rate of fraud in the banks and financial institutions. According to the KPMG Barometer index report of 2011, 520 cases valued at US \$ 3.3 billion was reported in 2011 (KPMG, 2011). The Central Bank of Kenya reported that majority $(74 \%)$ of commercial and financial institutions had weak risk management system. The main cause of weak risk management system in the report was due to lack of capacity among staff and low level of technology adoption (CBK, 2010). Similarly, within the East Africa region (Kenya, Uganda and Tanzania), majority (69\%) of the firms had weak ERM system (Deloitte, 2012). Ineffective ERM system means that risk was being managed in ad hoc, subjective way or ignored (Stulz \& Nocco, 2006). Uncoordinated risk management leads to; increase in risks, high rate of projects failure, disruption of operations, lack of coordination, damage in organizational reputation, high cost of regulatory scrutiny and high cost of capital (Hoyt \& Liebenberg, 2008; Manab, Kassim \& Othman, 2012 and Stulz \& Nocco, 2006). Similarly, weak ERM systems in a country make firms to be less competitive and hence low investment. The purpose of the study was to find out the effect of firm size on ERM for the listed firms in Kenya.

\subsubsection{Theoretical Review}

In this study firm size is looked at in terms of capital structure, asset value and sourcing of finance. According to Kamar, Rajan and Zingales (2001), what determines a firm size is the ownership of physical assets which are critical resources. Adam Smith (1776) looked at the size of a firm in terms of extent of specialization. The neoclassical theory of firm size is Lucas (1978). Lucas looked at the firm size in terms of per capita capital in form of investment return and research and development. A firm value is measured by; (cash flows to firm) $(1+\mathrm{g}) /$ cost of capital (Damodaran, 2008). Ownership structure is determined by percentage of individual ownership to percentage of institutional ownership.

Tahir \& Razali (2011) argued that the use of debt finance act as a leverage in the sense that objectives that goes with debt capital financing is less than obligations on equity capital. This therefore justify the Pecking order theory which states that firms prefer to use their internal sources of financing to equity financing if internal financing does meet the needs of the firm, otherwise they can use external financing. Under pecking order theory, the financing decision procedure starts with a firm using bank loan, then preference shares before issuing ordinary shares. Thus the profitable firms are less likely to opt for debt for new projects because they have available funds in the form of retained earnings (Gill \& Mathur, 2011 and Pandey, 2009). 
Waweru and Kisaka (2012) alluded that larger firms' organization were more likely to complex to have operations and therefore are exposed to threatening events. ERM has potential to provide an organization with competitive advantages which can be used by large firms to initiate strategies that can build synergies that can translate to cost advantages, differentiation and focus (Woon et al, 2011). Yazid et al (2012) explained the importance of managing assets categorized into tangible and intangible assets as they are extremely useful in supporting ERM activities that could provide overall benefits to the firms concerned. In support to this, Hoyt and Liebenberg (2008) in justify why large firms are more likely to engage in ERM, apart from being complex and face a wider array of risks; they have the institutional size to support the administrative cost of ERM program. Gordon, Loeb and Tseng (2009) also suggest that there is a positive relation between the size of a firm and its need for an ERM system.

Another factor of firm characteristic is ownership structure of an organization. Ownership structure is looked in two dimensions, concentration of ownership and legal status which control firm's activities. In this context the decision to implement ERM as an integrated approach could also come directly from a company's board of directors (Yazid, Razali \& Hussin, 2012). Hoyt and Liebenberg (2008) found out that pressure from external stakeholders is regarded as an important driving force behind the adoption of ERM program. A company with institutional share ownership is more likely to have pressure from such group to adopt ERM program. Therefore, we expect that firms with higher percentage of institutional ownership will be more likely to engage in ERM than those with individual ownership. Tahir and Razali (2011) explain that institutional ownership influences any decision by management of companies and therefore an important variable. Altuntas, Stolzle, and Hoyt (2011) found out that group affiliation in ownership is positively related to the likelihood of adopting ERM. Ownership structure in this study will be measured in terms of percentage of institutional shareholders vices individual shareholders.

\subsection{Conceptual framework}

In this study the conceptual framework is based on two indicators that measure the independent variables namely, net assets and capital employed. The dependent variable is enterprise risk management (ERM) is measured by financial performance of the listed firms in the Nairobi Stock Exchange (NSE). Financial performance is determined by calculating average of EPS for five years (2007-2011).

\section{Independent variable}

Dependent variable

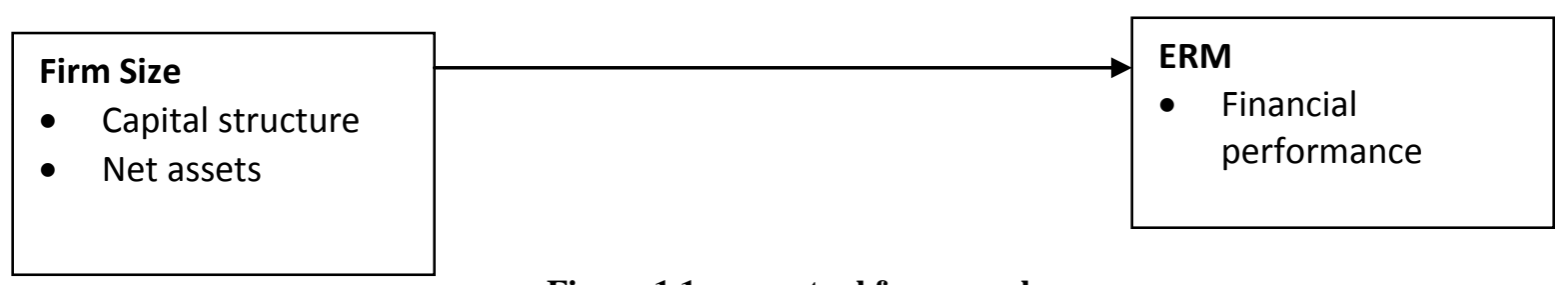

Figure 1.1 conceptual framework

\subsubsection{Capital structure}

Long term claims form the capital structure which represents the proportionate ratio between debt and equity capital. The financing or capital structure decision influences managerial decision targeted to improve on shareholder's return and risk. Capital structure determines the debt-equity mix which has an implication on earnings and risks and ultimately cost of capital and market value of a firm (Pandey, 2009). Leverage is acceptable and useful for the purpose of a company's future growth (Yazid et al, 2012). Companies that use leverage must balance the ratio of debts to equity to avoid financial distress and risk of bankruptcy.

\subsubsection{Net Asset Value}

The net asset value of a firm is the amount by which total asset exceed total liabilities. In business net asset value is used to assess the profitability, credit status and solvency position of a firm. The net asset is determined by adding the non current asset and current asset and subtracting current liabilities. The net asset can also be used to measure the net worth of the business, even though there are other factors that can contribute to value of a firm. Yazd et al (2012) added that assets represent the economic resources for companies.

\subsection{Empirical Evidence}

Golshan \& Rasid (2012) investigated factors that lead to enterprise risk management adoption. The results show that there are factors to consider before making decision to implement ERM. The key factor identified in the study is firm size. The study suggested that by considering the firm size before adopting ERM there is higher chance that the ERM will success. 
Yazid et al (2012) examined determinants of enterprise risk management for public listed companies in Malaysia. The results show that for effective implementation of ERM a lot of resources are required and therefore large firm have enough of such resources. similary, the study also found out that larger multinationals were more likely to be involved in risk management than local firms.

Staniee (2011) looked at the factors that determine the functioning of risk management systems. The results show that the primary barrier to the proper functioning of risk management system in organizations among others is limited resources. Lassar, Haar, Montalvo \& Hulser (2010) on the other hand, examined the determinants of strategic risk management in emerging markets. The findings from the study shows that firms endowed with resources and networks were more likely to implement strategic risk management.

In other studies on ERM, Tahir and Razali, 2011; Jafari et al, 2011 and Grace et al, 2010, Hoyt and Liebenberg (2009) examined the relationship between ERM and firm value for public listed firms in Malaysia, the relationship between total risk management and company's performance in Malaysia and the value of investing in ERM in Malaysia insurance industry by focusing on cost and revenue efficiency to evaluate the value of ERM and the value of ERM in US insurance industry by looking at the effects of cost associated with mitigation of risks, bankruptcy, regulatory scrutiny costs and taxation burden. The results from the studies concurred that firm size influences the effectiveness of ERM.

\section{Methodology}

This study used descriptive research design which was appropriate in describing the state of affairs as it existed. Data was collected using two documents; a questionnaire and a survey sheet. Data collected using questionnaire was from primary source targeting ERM managers while survey sheet was used to collect data from financial statement submitted to Nairobi Securities Exchange (NSE). All the firms that had submitted their audited financial statements were sampled and a structured self administered questionnaire was used to collect data.

Both reliability and validity tests were done, Cronchbach's alpha computed was 0.707 which was more than 0.7 and the factor loading for all the items used in the questionnaire was between 0.599 and 0.949 which were more than 0.4. The questions therefore were considered for further analysis. Descriptive data was analyzed in form of percentage, mean and standard deviation. Further statistics analysis was done in form of correlation and regression analysis.

\section{Findings and Discussion}

The findings from the study are provided in the tables and statistical data. Factor analysis was done to reduce the data to a meaningful and manageable set of factors as well to ascertain the suitability of all the variables. This was done to discover patterns among the variables and determine if the underlying combinations of the original variables can summarize the original set. Factor analysis was also done to reduce a vast number of variables to a meaningful, interpretable and manageable set of factors.

Factor analysis show the correlation matrix in which the inter-correlations between the studied variables are presented. Factor loadings are the correlation of the original variables with a factor. The variable had 14 items that were tested and all the items that were tested had a factor score of over 0.4 showing that the items were meaningful response.

The respondents were asked to provide information on Likert scale $1-5$, dichotomous and open ended questions. The Likert scale $1-5$ questions were rated as; $1=$ strongly disagree, $2=$ disagree, $3=$ neutral, $4=$ agree and $5=$ strongly agree; dichotomous question was rated as $1=$ no and $2=$ Yes and open ended questions were used to get further information and clarification on issue(s) not adequately captured in the likert scale questions or dichotomous questions. Open ended questions were analyzed using content analysis method. Orodho (2005) alluded that content analysis examines the intensity with which certain words, points of view, and emotionally laden words are used.

\subsection{Effects of firm size on ERM}

From the empirical evidence, shareholders and institutional ownership influences adoption and effectiveness of enterprise risk management. The results from the study concur with the empirical findings. Table 3.1 shows that $57.4 \%$ of respondents indicated that shareholders have an influence on ERM adoption while the top management, board of directors and middle level managers were indicated as most effective in ensuring the success in ERM rated at $94.1 \%, 91.1 \%$ and $79.4 \%$ respectively. The main sources of funds for long term projects for the firms are; equity capital and long term loan rated at $82.4 \%$ and $76.4 \%$ respectively. The findings is consistent with other studies on ERM that ownership structure of an organization influences decision making in democratic process where majority shareholders influences policy decisions (Yazid, Razali \& Hussein, 2012). Tahir \& Razali (2011) alluded that institutional ownership influences decisions on ERM. 
Effects Of Firm Size On Enterprise Risk Management Of Listed Firms In Kenya

Table 3.1: Effects of ownership structure on ERM

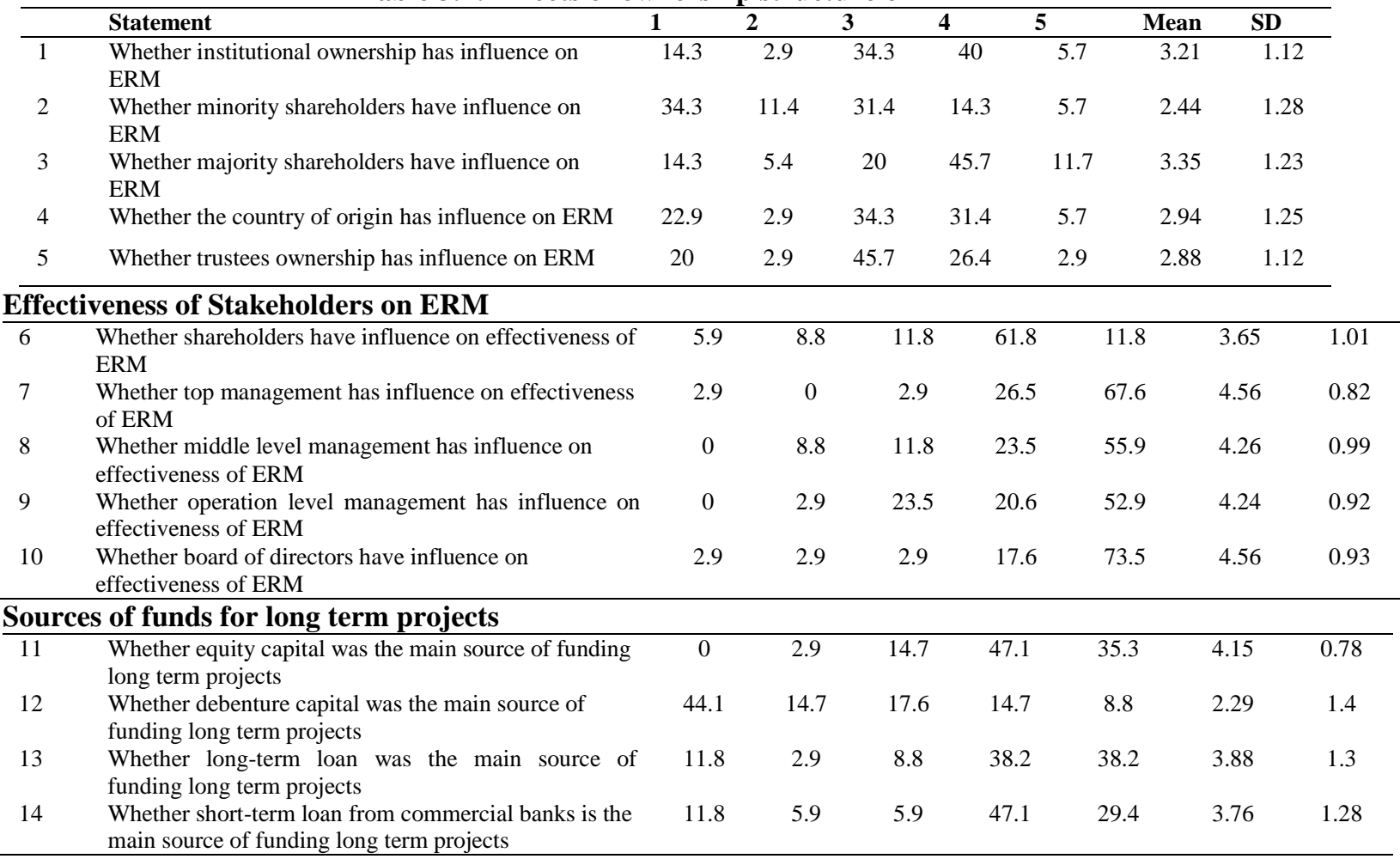

\subsection{Factors that influence effectiveness of ERM}

Support from top management, resource endowment and risk attitude are the main factors that influence effectiveness of risk management. Table 3.4; shows $42.4 \%$ of the respondents indicated that top management influence effectiveness of ERM, 30.3\% indicated that resource availability influence effectiveness of ERM, 18.2\% indicated that effectiveness of ERM was influenced by risk attitude by all firms' stakeholders $6.1 \%$ did not indicate any factor and 3\% indicated that regulators such as industry regulators and capital market influence effectiveness of ERM.

Table 3.2: Factors that influence effectiveness of ERM

\begin{tabular}{lc}
\hline Factor & Valid Percent \\
\hline No Factor & 6.1 \\
Risk Attitude & 18.2 \\
Regulators & 3.0 \\
Resources & 30.3 \\
Top Management support & 42.4 \\
Total & 100.0 \\
\hline
\end{tabular}

\section{3: Role of shareholders' financing decisions}

The key role of shareholders in financing decisions are; approving of projects by voting at annual generating meetings, sourcing of funds to finance business operations and approving of projects to be undertaken. Table 3.3; show participation of shareholders in long term financing decisions. $58.8 \%$ of the respondents indicated that shareholders participated in long term financing decisions by voting at the annual general meetings (AGM), 23.5\% indicated that they were involved in sourcing of funds, $8.8 \%$ indicated that they were involved in approval of budget and $5.9 \%$ indicated that shareholders were playing the oversight role.

Table 3.3: Shareholders' Participation in long term financing Decisions

\begin{tabular}{lc}
\hline & Valid Percent \\
\hline Voting at AGM & 58.8 \\
Sourcing of funds & 23.5 \\
Approval of projects & 8.8 \\
Oversight role & 5.9 \\
Total & 100.0 \\
\hline
\end{tabular}




\subsection{Role of directors in risk management}

Directors of the listed firms in Kenya play a key role in risk management. Table 3.4 show the rating of directors in ERM process. Through dichotomous question, respondents were asked to indicate whether directors had any role in risk management. $97.1 \%$ of the respondents indicated that directors had a role in risk management while $2.9 \%$ of the respondents indicated that directors did not have any role in risk management.

Table 3.4: Directors' Involvement in risk management

\begin{tabular}{lc}
\hline Respond & Valid Percent \\
\hline Yes & 97.1 \\
No & 2.9 \\
Total & 100.0 \\
\hline
\end{tabular}

\subsection{Role of directors in risk management}

The success of ERM for the listed firms in Kenya is attributed to the directors of the firms. They participate in risk management by; developing enterprise risk management policies, monitoring enterprise risk management and communicating enterprise risk management. Table 3.5 shows that $41.1 \%$ of the respondents indicated that the role of directors is to develop risk management policies, $32.4 \%$ indicated that directors monitor risk management within the firms and 20.6 of the respondents indicated that the role of directors is to communicate enterprise risk management policies and strategies to staff and other interested stakeholders.

Table 3.5: Role of Directors in risk management

\begin{tabular}{lc}
\hline & Valid Percent \\
\hline Non/ No role & 5.9 \\
Developing ERM policies & 41.1 \\
Monitoring ERM & 32.4 \\
Communicating ERM report & 20.6 \\
Total & 100.0 \\
\hline
\end{tabular}

\subsection{Role of directors in capital financing decisions}

Capital financing decisions affects capital structure, which is the ratio of equity to debt capital. A firm that uses high debts to finance its operations risks liquidation or bankruptcy due to failure to owner its obligations in time. The key role of directors in this process of capital financing is; oversee contracts entered in financing business, approval budgets for projects developed by management and identify appropriate sources of funds for the business. Table 3.6, shows the major role of directors in capital financing decisions as indicated by the respondents. $58.8 \%$ of the respondents indicated that directors were involved in oversight role, $14.7 \%$ indicated that directors were involved in capital financing through approval of budget prepared by the management, $23.5 \%$ of the respondents indicated that directors were involved in sourcing of funds to finance capital projects and $2.9 \%$ of the respondents indicated that directors did not have any role in capital financing.

Table 3.6: Role of Directors in Capital Financing Decisions

\begin{tabular}{lc}
\hline & Valid Percent \\
\hline No role & 2.9 \\
Approval of budget & 14.7 \\
Oversight role & 58.8 \\
Sourcing of funds & 23.5 \\
Total & 100.0 \\
\hline
\end{tabular}

\subsection{Linear Regression Analysis for firm's Characteristics and Enterprise risk management}

The objective of the study was to investigate the influence of firms' characteristics on Enterprise Risk Management. The investigation involved testing of the null hypothesis to confirm whether there is no significant relationship between firms' characteristics and enterprise risk management of the listed firms in Kenya. The relationship was measured by a linear regression model which compared firm's characteristics and enterprise risk management. The following analysis were done; Pearson correlation, coefficient of determination and ANOVA. Hoyt and Liebenberg (2008) argued that large firms are more likely to engage in ERM due to availability of resources to implement and meet administrative costs of ERM.

\section{Pearson correlation of firms' characteristics and ERM}

The result from the Pearson correlation analysis shows a high correlation between firms' characteristics and enterprise risk management. The values of $r$ lie between +1 and -1 . Positive values for $r$ indicate positive correlation between two variables. The Pearson correlation analysis shows the value of 0.722 with a p-value of 0.000 , since the value is closer to 1 then the analysis confirm high relationship between firms' characteristics. This means that an increase in firm size leads to improvement in efficiency of enterprise risk management. 
3.7 Correlations between firm's performance and financial performance

\begin{tabular}{|c|c|c|c|}
\hline & & Firms' characteristics & financial performance \\
\hline \multirow{3}{*}{ Firms characteristics } & Pearson Correlation & 1 & $.722^{* *}$ \\
\hline & Sig. (2-tailed) & & .000 \\
\hline & $\mathrm{N}$ & 33 & 33 \\
\hline \multirow{3}{*}{ financial performance } & Pearson Correlation & $.722^{* *}$ & 1 \\
\hline & Sig. (2-tailed) & .000 & \\
\hline & $\mathrm{N}$ & 33 & 33 \\
\hline
\end{tabular}

**. Correlation is significant at the 0.01 level (2-tailed).

The regression analysis model was used to predict the effect of firms' characteristics on financial performance of the listed firms in Kenya. The model summary in table 3.8 shows the effects of firms' characteristics on financial performance for firms that had implemented ERM and those that had not implemented ERM. In comparison, the firms that had implemented ERM had a higher value of R (0.851) while those with ERM had value of 0.73 . The $\mathrm{R}^{2}$ for the firms had implemented ERM was 0.725 ; this means that a change in a unit of firms explains $72.5 \%$ of changes in financial performance of the listed firms in Kenya.

3.8: Model Summary ${ }^{\text {b,c }}$ for firms' characteristics and financial performance

\begin{tabular}{|c|c|c|c|c|c|c|c|c|c|c|}
\hline \multirow[t]{2}{*}{ Model } & \multicolumn{2}{|r|}{$\mathrm{R}$} & \multirow[t]{2}{*}{ R Square } & \multirow{2}{*}{$\begin{array}{c}\text { Adjusted R } \\
\text { Square }\end{array}$} & \multirow{2}{*}{$\begin{array}{l}\text { Std. Error of } \\
\text { the Estimate }\end{array}$} & \multicolumn{5}{|c|}{ Change Statistics } \\
\hline & $\begin{array}{l}\text { risk mgt method } \\
=\text { ERM system } \\
\text { (Selected) }\end{array}$ & $\begin{array}{l}\text { risk mgt method = } \\
\text { ERM system } \\
\text { (Unselected) }\end{array}$ & & & & $\begin{array}{l}\text { R Square } \\
\text { Change }\end{array}$ & F Change & df1 & df 2 & Sig. F Change \\
\hline 1 & $.851^{\mathrm{a}}$ & .373 & .725 & .700 & .31325 & .725 & 28.98 & 1 & 11 & .000 \\
\hline
\end{tabular}

a. Predictors: (Constant), Net Asset Value

b. Unless noted otherwise, statistics are based only on cases for which risk mgt method = ERM system.

c. Dependent Variable: financial performance

The decision on whether to accept or reject the null hypothesis was done after the ANOVA analysis to determine the $F$ value. Through ANOVA, either the null hypothesis $\left(\mathrm{H}_{\mathrm{o} 1} \neq \beta_{1}\right)$ or the alternative hypothesis $\left(\mathrm{H}_{\mathrm{A} 1}\right.$ $=\beta_{1}$ ) is accepted or rejected. Using ANOVA model in table 3.9 the analysis of the difference and association of the independent and dependent variables was determined. The calculated $\mathrm{F}$ value at $.05 \%$ level of confidence is 28.980 while the expected $F$ value at $.05 \%$ level of confidence at 1 and 11 degrees of freedom is 4.844 . Since the calculated $\mathrm{F}$ value is greater than the expected $\mathrm{F}$ value then the null hypothesis is rejected and the alternative hypothesis is accepted. The conclusion therefore is that there is significant relationship between firms' characteristics and financial performance of the listed firms. The results concur with the empirical evidence such as Hyot and Liebenberg (2008), that a firm with adequate resources was more likely to implement ERM.

Table 3.9: ANOVA

\begin{tabular}{ccccccc}
\hline & Model & Sum of Squares & df & Mean Square & F & Sig. \\
\hline \multirow{2}{*}{1} & Regression & 2.844 & 1 & 2.844 & 28.980 & \\
& Residual & 1.079 & 11 & $.000^{\mathrm{c}}$ & \\
& Total & 3.923 & 12 & & \\
\hline
\end{tabular}

a. Dependent Variable: financial performance

b. Selecting only cases for which risk mgt method = ERM system

c. Predictors: (Constant), Firms' Characteristics

Since the ANOVA analysis shows that there is a significant relationship between firms' characteristics and enterprise risk management then to predict impact of effects a univariate model is used. Table 3.10 show the determination of constant, beta and standard error in the univariate model $Y=\alpha+\beta_{1} X_{1}+\varepsilon$. The table shows the following values substituted for; $\alpha, \beta_{1}$, and $\varepsilon$ as; 1.277 for $\alpha, 0.851$ for $\beta_{1}$ and 0.273 for $\varepsilon$ respectively. The model for predicting the effects of firms' characteristics on financial performance is expressed as; $\mathrm{Y}=1.277+$ $0.851 \mathrm{X}_{1}+0.23$. This model is therefore used for predicting the value of $\mathrm{Y}$ given $\mathrm{X}_{1}$.

Table 3.10: Cofficient of financial performance and firms' characteristics

\begin{tabular}{|c|c|c|c|c|c|c|c|c|c|}
\hline \multirow[t]{2}{*}{ Model } & \multicolumn{2}{|c|}{$\begin{array}{c}\text { Unstandardized } \\
\text { Coefficients }\end{array}$} & \multirow{2}{*}{$\begin{array}{c}\text { Standardized } \\
\text { Coefficients } \\
\text { Beta }\end{array}$} & \multirow[t]{2}{*}{$\mathrm{t}$} & \multirow[t]{2}{*}{ Sig. } & \multicolumn{2}{|c|}{$\begin{array}{l}95.0 \% \text { Confidence Interval } \\
\text { for B }\end{array}$} & \multicolumn{2}{|c|}{$\begin{array}{l}\text { Collinearity } \\
\text { Statistics }\end{array}$} \\
\hline & B & Std. Error & & & & Lower Bound & Upper Bound & Tolerance & VIF \\
\hline (Constant) & 1.277 & .273 & & 4.671 & .001 & .675 & 1.879 & & \\
\hline $\begin{array}{l}1 \text { Net Asset } \\
\text { Value }\end{array}$ & .386 & .072 & .851 & 5.383 & .000 & .228 & .544 & 1.000 & 1.000 \\
\hline
\end{tabular}


b. Selecting only cases for which risk mgt method = ERM system

The distribution of data for the dependent variable (financial performance) as shown in figure 3.1 is a linear correlation. As the firms grow in terms of resources the financial position also grows.

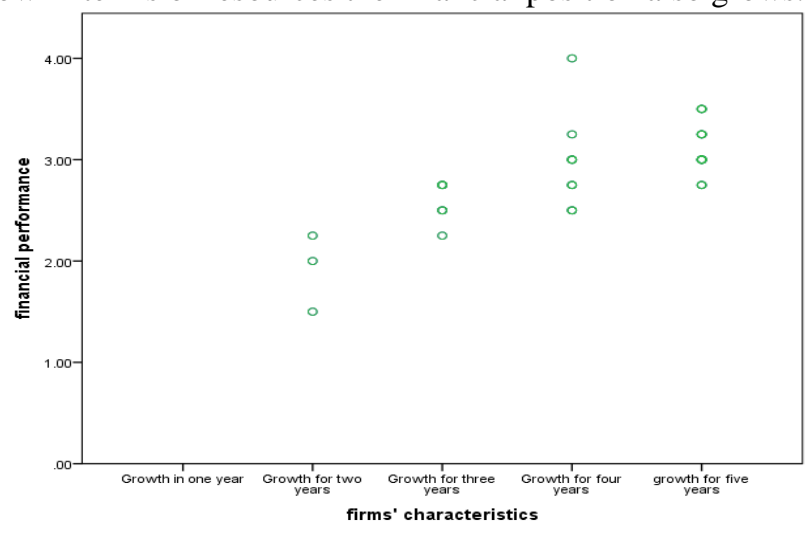

Figure 3.1 Scatter plots for firms' characteristics and financial performance

Figure 3.2 shows the distribution of data for the dependent variable (Enterprise Risk Management). The distribution symmetrical that is normal. This means that the values of the dependent variables are normally distributed (mesokurtic) the probability of extreme values is low. The mean, mode and median are equal.

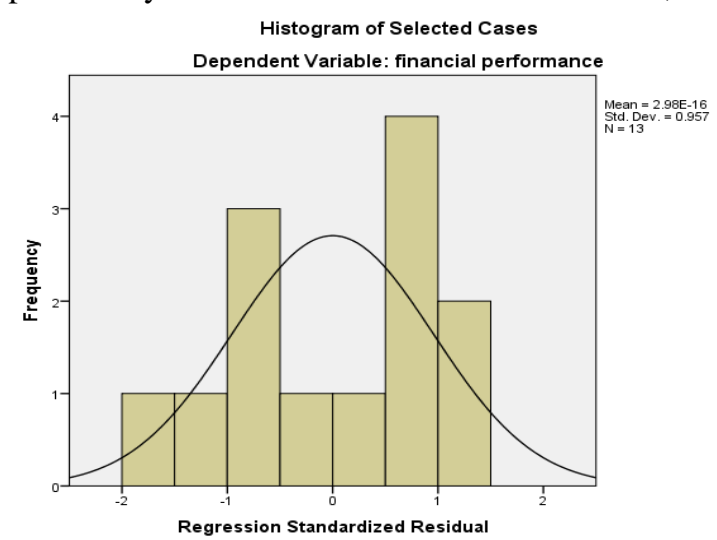

Figure 3.2 Histogram the distribution of financial performance

\section{References}

[1]. AM. Best Company (2013). Country Risk report for 2013. Available at, www.ambest.com/rating/cr/report/kenya.pdf

[2]. Anderson, Boyle, Brady, Bridge, Bromfield, Chamblee,...,Liebfried (2004). Committee of Sponsoring Organization of Treadway Commission (COSO): ERM-Integrated Framework, Application Techniques, New York: COSO

[3]. Africa Insurance Agency (2009).Annual Reports and Accounts of 2009: Africa Insurance Agency, available at;www.atiaca.org/annualreport2009.pdf, retrieved on 28/6/2012.

[4]. Althonayan A., Keith J and Misiura (2011). Aligning Enterprise Management with Business Strategy and

[5]. Information systems, European, Mediterranean and Middle Eastern Conference on Information Systems, 2011 May 30-31 2011 pg 109-129.

[6]. Altuntus M., Berry-Stolzle and Hoyt R. (2011).Dynamics Determinants of Enterprise Risk Management Adoption inthe PropertyLiability Insurance Industry: Evidence from Germany. Geneva Association Newsletter, 64 July,2011, International Association for study of Insurance Economics, .

[7]. Beasley, Mark, Clune R. and Hermanson (2006). Enterprise Risk Management: Analysis of factors associated with the extent of implementation. Journal of Accounting and Public Policy No. 24(6).

[8]. Beasley, Hancock and Branson (2009).COSO's Report on Enterprise Risk Management Current State of Enterprise Risk Oversight and Market Perceptions. Durham: COSO. Second Edition. New York: Oxford University Press.

[9]. Central Bank of Kenya (2011).Risk Management Survey for the Banking Sector. Nairobi: Central Bank of Kenya Publication.

[10]. Cooper and Schindler (2011).Business Research Methods. New York: McGraw-Hill.

[11]. Committee of Sponsoring Organizations of the Treadway Commission (COSO) (2009).Strengthening Enterprise Risk Management for Strategic Advantage. Available at http//:www.coso.org/documents/coso. Accessed on20 June, 2012.

[12]. Dafikpaku E. (2011). The strategic implications of enterprise risk management: a framework. www.ermsymposium.org/2011/pdf/Dafikpaku.pdf.

[13]. Deloitte (2012). Enterprise risk management survey report of 2012, where do you stand. Nairobi. Deloitte Publication

[14]. Golshan M. and Rasid A. (2012). Determinants of Enterprise Risk Management Adoption: An Empirical Analysis of Malaysian Public Listed Firms. International Journal of Social Science.

[15]. Golshan M. and Rasid A. (2012). What Leads Firms to Enterprise Risk Management Adoption? A Literature 
[16]. Hoyt and Liebenberg (2008).The Value of Enterprise Risk Management: Evidence from the U.SInsuranceIndustry.Http://www.risknet.de/typo3conf/ext/bx elibrary accessed on 3/1/2012.

[17]. Institute of Management Accountant (2011).Enterprise Risk Management. New York. IMAKaplan R., Colica J.,Ranganath M. and Zubrow B. (2009).Enterprise Risk Management, Summit Report 2008.Havard: Havard Business School.

[18]. ISACA (2012). A Business Framework for Governance and Management of enterprise IT. Algonquin Road, USA. Enterprise GRC Solutions Inc.

[19]. Kenya Institute of Public Policy Research Analysis (2009).Kenya Economic Report 2009.Building a Global Competitive Economy. Nairobi: KIPPRA Publication.

[20]. Kombo and Tromp (2006).Proposal and Thesis Writing, an Introduction. Nairobi: Pauline Publications Africa.

[21]. Kothari C. R. (2009). Research Methodology. Methods and Techniques, $2^{\text {nd }}$ Edition. New Delhi: New Age International Publishers

[22]. Kumsuprom S., Corbitt B. Pittayachawan S. and Mingmalairaks (2010).Determinants of Successful ICT Risk Management in Thai Organizations. pp 107, http://www.pacis.net.org/file/pdf, accessed on 24th March, 2012.

[23]. Lai F. and Samad F. (2011). Enterprise risk management and the empirical determinants of its implementation. Journal onInternational Conference on Business and Economics.

[24]. Manab N. Othman S. and Kassim I. (2012). Enterprise-Wide Risk Management Best Practices: The Critical Success Factors, OIDA. International Journal for Sustainable Development. pp 87-92

[25]. Meulbroek (2002).Integrated Risk Management for the firm, a Senior Manager's Guide. Boston: Harvard Business School Publication.

[26]. Mugenda (2008).Social Science Research: Theory and Principles, Nairobi: Applied Research and Training Services.

[27]. Muralidhar K. (2010). Enterprise Risk Management in the Middle East oil industry: An Empirical Investigation Across GCC Countries. International Journal of Energy Sector Management.Vol. 4 Iss: 1 pp 59-86

[28]. Nairobi Securities Exchange (2011).NSE Share Price Index analysis for the month of November.http://www.nse.ac.ke/listing/6/12/2011.Assessed on 6/12/2011.

[29]. Nairobi Securities Exchange (2012). Nairobi Securities Handbook 2012, Nairobi, NSE publication.

[30]. Nayak and Mohanty (2009). The Importance of ICT Risk Management in Small to Medium- Sized $\quad$ Enterprises, United Kingdom.Journal for Technology Engineering Sciences.

[31]. Ngugi D. (2005).Growth of Nairobi Stock Exchange Primary Market. Discussion Paper. No. 47, KIPPRA.

[32]. Nofsinger, Adair \& Cornett (2009). Finance Applications and Theory. New York: McGraw-Hill Irwin.

[33]. Nocco and Stulz (2006). Enterprise Risk Management: Theory and Practice. Journal of Appeal Corporate Finance.No. 4.

[34]. Pagach D. and Warr R. (2010).The Effects of Enterprise Risk Management on FirmPerformance.Ssrn:http://ssrn.com/abstract=1155218.www. Accessed on 12 ${ }^{\text {th }}$ March,2012.

[35]. Pincker R. (2008). An empirical examination of competing theories to explain continuous disclosure technology adoption intention using XBRL as an example of technology. pp 81-96

[36]. Pricewaterhousecoopers (PWC), (2012). Rising to the Next Flow. A Kenya perspective on 2012 state of the Internal Audit Profession Study. Nairobi: PWC Publication.

[37]. Protiviti (2006).Guide to Enterprise Risk Management, Frequently Asked questions. New York: Protiviti Inc.

[38]. Orodho (2005).Elements of Education and Social Science Research Method. Nairobi: Masola Publishers.

[39]. Ranong P. Phuenngam (2009). Critical Success Factors for effective risk management procedures in financial industries, Umea. Thailand.

[40]. Sekaran U. (2010).Research Methods for Business, a Skill Building Approach, $4^{\text {th }}$ Edition. Carbondale: John Wiley and sons.

[41]. Staniec I. (2011). Factors that Determine the Functioning of Risk Management Systems. International Journal of Social Science.

[42]. Straub, D.W and Welke, R.J (1998). Coping With Systems Risks: Security Planning Models for Management Decision Making, MIS Quarterly. No. 20 (4), pp 441-469

[43]. Tahir and Razali (2012). The Relation between Enterprise Risk Management and Firm Value: Evidence from Malaysian Public listed Companies. International Journal of Economics and Management. No. 2, pp 32-41.

[44]. Waweru and Kisaka (2012). The Effect of Enterprise Risk Management implementation on the value of companies listed in the NSE. AAA 2012 Management Accounting Paper, available at http://ssrn.com/abstarct=1907248.

[45]. Watt C. (2008). Enterprise Risk Information in Financial Services Organizations.New York: Economic Intelligence Unit.

[46]. West (2006).An Introduction to Modern Portfolio Theory: Markowitz CAPM. APT and Black-Litterman.

[47]. Woon L., Azizan N. and Smad F. (2011). A Strategic Framework for Value EnhancingEnterprise Risk Management .Journal of Global Business and Economics.No. 1

[48]. Yazid, Razali\&Hussin (2012), Determinants of enterprise management: A proposed frameworkfor Malaysia public listed companies, Journal pp 202-207

[49]. The Republic of Kenya (2012). Kenya Gazette No. 3362 on guidelines on corporate governance practices by public listed companies in Kenya. Government Printer.

\section{Appendix I}

Table for Reliability measurement on firms' characteristics Statistics

\begin{tabular}{lcc}
\hline Variable & Cronbach's Alpha & N of Items \\
\hline Firm's characteristics & .707 & 19 \\
\hline
\end{tabular}

\section{Appendix II}

Table 4.11: Component Matrix of effect of ownership structure on ERM

\begin{tabular}{ll}
\hline Statement & Factor loading \\
\hline Whether institutional ownership influences effectiveness of ERM & .834 \\
Whether minority shareholders influences effectiveness of ERM & .658 \\
Whether majority influences effectiveness of ERM & .713 \\
Whether country of origin influences effectiveness of ERM & .657 \\
Whether trustees influences effectiveness of ERM & .767 \\
Whether middle level management influence effectiveness of ERM & .949 \\
Whether operation management influence effectiveness of ERM & .929 \\
\hline
\end{tabular}


Whether top Management influence effectiveness of ERM .833

Whether Board of Directors influence effectiveness of ERM

Whether Shareholders influence effectiveness of ERM .801

Whether Debentures was used to fund capital projects

831

Whether Equity capital was used to fund capital projects

.686

Whether Long term loans was used to fund capital projects

Whether short term loans was used to fund capital projects

.436

Extraction Method: Principal Component Analysis. 